\title{
A Novel Stem Cell Paradigm: Past Controversies, Present Challenges \& Future Prospects
}

\author{
Shivani Vakodikar*, Jaymesh Thadani and Prashant Kshatriya
}

Total Potential Cells $(P)$ Ltd, Gujarat, India

\begin{abstract}
Stem Cell therapeutics is a revolutionary change in the world of modern medicine. These magical bullets have evolved as alternative therapeutic modality to conventional method. Different countries have passed legislation to undertake the human embryonic stem cell research. Developed countries like USA and, Australia have banned the exploration of hESCs for research purpose. While on the other hand, developing countries have made stringent regulatory approvals and permitted the research. To avoid ethical conspiracy, induced Pluripotent stem cells with same potential with that of hESCs raised scientific breakthrough. The major flaw related to iPSCs was teratoma formation. Thus to avoid hESCs controversy and loopholes of iPSCs, application of adult stem cells came into existence. To manufacture clinical grade stem cells, cell identity, purity and genomic stability for long term culturing is to be assured. For this, various cell culture and molecular techniques are reported to assess the quality of stem cells. For sterility and safety, culture contamination, viability and presence of endotoxins/pyrogens relevant tests are noted. The autologous and allogenic criteria are discussed related to safety of cells. In nutshell, ethical concern is resolved by developing adult stem cells and quality control for dispensing cell is established by cell identity, purity, genomic stability, sterility and safety. Thus, emerging stem cells in the era of biotherapeutics harbors a promising role for incurable degenerative conditions
\end{abstract}

Keywords: Stem cells; Ethics; Quality control; Safety

In past decade, stem cell therapy has gained wide attention in modern medicine. The stem cell based therapy has evolved as alternative therapeutic modality to conventional method. The well-established properties of Stem Cells (SCs) and mechanism of actions has changed the current frontier of therapeutics. They have capacity to translate in tri-germinal layers i.e. ectoderm, mesoderm and endoderm lineages. Moreover they are immunonaive and do not elicit immune response, thus immune-suppression drugs are not needed. The human leukocyte antigen- DR (HLA-DR) is absent which nullifies the graft vs host rejection. They possess honing potential for lesion site. The stem cells hone to the inflamed region or lesion site. They reduce inflammation by secreting cytokines in paracrine fashion. Depending upon prevailing microenvironment they adhere to the lesion site, multiply; increase the population and differentiate into specialized tissue. Thus repair of degenerated tissue and regeneration process is justified.

Currently, the scientific technocrats are finding the in-depth science behind the mechanism of action. The nature of micro-environment, cell signaling pathways and molecular level science is the base of mining the new paradigm. Besides these, other aspects needs to be discussed \& resolved to accept the new paradigm of therapeutics. For dispensing stem cells off the shelf certain parameters should be taken into account. The ethical controversies, quality of stem cells in terms of cell identity, purity \& genomic stability and safety concerns are crucial factors for manufacturing and future prospects of stem cells.

The human embryonic stem cells offer hope for novel therapies, but their use in research has been hotly debated. Thomson et al. reports [1], a 5th day human embryo consists of 200-250 cells comprising of trophoblast - outer most layer of blastocyst. The human Embryonic Stem Cells (hESCs) are harvested from inner cell mass which requires removal of trophoblast. This eliminates the potential for further development of embryo. Thus hESCs are categorised in impermissible area of research as it involves unjust killing of innocent human beings. The opponent of embryonic stem cell research also argues that research violates the sanctity of life and is tantamount to murder.
Governments around the globe have passed legislation to regulate human embryonic stem cell research. In the United States [2], laws prohibit the creation of embryos for research purposes. Scientists instead use "leftover" embryos from fertility clinics with informed consent from donors. The Stanford Encyclopaedia of Philosophy [3] opposed the harvesting of hESCs because it involves the destruction of the human embryo. Some stem cell researchers are working to develop techniques of isolating stem cells that are as potent as embryonic stem cells, but do not require a human embryo. The Parliament of Australia [4], raised key ethical concerns in embryonic stem cell research viz. embryo have status as, "human being/person, potential person, divine creation, human life with intrinsic values, of mere body parts, are harmed by their destruction and most pivotal are they created for research purpose?"

In light of the limits to federal funding access for hESCs research, philanthropic organizations and some state governments have stepped in to support hESCs research. California Institute for Regenerative Medicine has approved a proposition to support research on hESCs and human adult stem cells. China, Japan and some European countries, notably Belgium and Sweden, have similarly liberal policies regarding the creation of new hES cell lines. In view of Indian Council of Medical Research [5], National guidelines for Stem Cells Research 2017 have classified hESCs in permissible area of research, confined to spare embryo with stringent regulatory approvals and informed consent. The Netherland researcher Guido de Wert et al. [6], addresses

*Corresponding author: Shivani Vakodikar, Total Potential Cells (P) Ltd, Gujarat, India, Tel: 09099097874; E-mail: shivanivakodikar@yahoo.com

Received September 27, 2017; Accepted October 09, 2017; Published October 13, 2017

Citation: Vakodikar S, Thadani J, Kshatriya P (2017) A Novel Stem Cell Paradigm: Past Controversies, Present Challenges \& Future Prospects. J Stem Cell Res The 7: 403. doi: 10.4172/2157-7633.1000403

Copyright: (C) 2017 Vakodikar S, et al. This is an open-access article distributed under the terms of the Creative Commons Attribution License, which permits unrestricted use, distribution, and reproduction in any medium, provided the original author and source are credited. 
some ethical issues in the context of state-of-the-art-research in the development of stem cell based transplantation therapy. Based on the principle of proportionality and subsidiarity, ban on creating embryos for instrumental use in research is morally unjustified.

The debate over hESCs research is becoming increasingly irrelevant because of other available alternatives. To waive off ethical questions regarding hES cells, stem cell researchers are working to develop techniques of isolating stem cells that are as potent as embryonic stem cells, but do not require a human embryo. Shinya Yamanaka and John Gurdon [7] reprogrammed adult cells to Pluripotent cells by inserting four transcription factors resulted in induced Pluripotent Stem Cells (iPSCs). The scientific breakthrough won noble prize in 2012. But, Gutierrez-Aranda [8] reported that iPSCs develops teratoma more efficiently and faster than hESCs which prevent them from being useful in cell replacement therapy.

Thereby, to overcome the retrospective ethics of hESCs and demerits of iPSCs, an innovative aperture, "Adult Stem Cells" came into the scenario. These stem cells similar to ESCs possess self-renewal and multidifferentiative potential however the differential potential is limited when compared to ESCs. The adult stem cells include haemopoietic stem cells, mammary stem cells, intestinal stem cells, mesenchymal stem cells, endothelial stem cells, neural stem cells, olfactory adult stem cells, neural crest stem cells and testicular cells. There are even reports suggestive of presence of adult stem cells in peripheral blood, bone marrow, umbilical cord, amniotic fluid, and placenta and are clinically safe and potential [9]. Adult stem cells are the utmost hope for many incurable disease like diabetes, cardiac disease, cartilage defects, haematological malignancies, Parkinsons's [10], Alzheimer's, Retinal Pigment Epithelium (RPE) [11], Age Related Macular Degeneration (ARMD), to name a few.

In the present time, adult stem cells are expanding the new avenues of regenerative medicine. The protocols for successful isolation, culturing, passaging and differentiation to specialized cells are available in open access domain. However the clinical grade manufacturing of stem cells requires quality control to ensure cell identity, purity, genomic stability and safety of cells. Firstly, the cell identity needs to be assayed based on cell proliferation, differentiation, immune modulatory capacity, and gene and protein marker expression (Cluster Differentiation i.e. CD 29, CD 44, CD 90, CD 105). The techniques involved are quantitative polymerase chain reaction (QPCR), ELISA, and flow cytometry. Digirolamo et al. [12] reported the shelf life of adult stem cells to be $\geq 25$ PD (population doubling).

Next, the purity of stem cell needs to be established such that only stem cells are present in the final manufactured product. The fibroblast are the type of cells which have some similar characteristic that of stem cells [13]. They have identical phenotype, similar growth potential and immune-modulatory function. Thus they need to be distinguished and ectomized in order to get pure stem cells. Lin HR, et al. [14] developed membrane filtration and membrane migration method for purification of stem cells. They used nylon mesh filter membranes with pore sizes ranging from 11 to $80 \mu \mathrm{m}$ to purify the stem cells. As the clinical studies often require highly purified cell population, Basu et al. [15] reported Fluorescence Activated Cell Sorting (FACS) as a preferred technique for obtaining $>98 \%$ purity of desired population.

The genomic instability of adult stem cells is yet another major concern for its clinical use as it enables the cells to acquire tumorogenic characteristics. Boozer et al. [16] employed miRNA expression to characterize and define the cell population; chromosomal SNP analysis and G-banding to determine karyotypic stability; and methylation pattern and telomerase expression to examine potential changes in epigenetic and chromosomal stability with prolonged in vitro culture of cells. Kundrotas et al. [17] reported that the karyotyping of adult stem cells by G- banding pattern at 7 passage, approximately $88 \%$ cells were of normal diploid karyotype. Moreover, 162 different genes related to stemness were evaluated with quantitative real time Polymerase Chain Reaction (RT -PCR) after 7 passage showed similarity with 156 genes. In contrast reports of Wang et al. [18] suggested that human umbilical cord derived mesenchymal stem cells cultured upto 30 passages to attain a large number of cells, developed genomic alterations which do not undergo malignant transformation.

The salient features presented above are related to clinical grade manufacturing of stem cells. But when it comes to the clinical treatment, there are various other parameters which need to be considered for dispensing stem cells and ensuring patient safety [19] Gram stain that detects for immediate signs of contamination. Long Term aerobic/ anaerobic cultures for 3-5 days for the detection for the presence of any slow growing bacteria that may not have been seen in gram stain. Limulus Amoebocyte Lysate (LAL) assays to ensure that sample is free of significant amounts of endotoxins and pyrogens. Trypan Blue Test can be done to assess efficacy of the isolation process and determine viability of cells. Wunsch assay will ensure that there is not an excess of proteolytic enzymes remaining in the sample.

There is irreconcilable dilemma with the safety of autologous and allogenic stem cells. People often misunderstand it with blood matching and HLA-typing and cryopreserving cord in banks for future application in blood relation. The autologous word itself suggests that stem cells harvested from patients own body. Thus it does not lead to any immediate, adverse systemic inflammatory reaction. Then, what about allogenic adult stem cells? The crystal clear concept behind no adverse event for allogenic cells is, they are immunonaive. They elicit immune response at minimal level and it lasts for 2-3 hours. However, advancement in cell processing techniques, the purity of cells is maintained upto $\sim 98 \%$ and thus chances for adverse event is eliminated. Feng et al. [20] observed fever, vomiting adverse events after intrathecal infusion of human umbilical cord blood derived stem cells, but it disappeared after symptomatic treatment and no serious event were found with 6 months of follow up. Hernigou et al. [21] studies found no increased cancer risk in patients after application of autologous cellbased therapy after an average follow-up period of 12.5 years.

In Conclusion regenerative medicine and stem cell provides a universal paradigm in palliative interventions. The ethical controversy of hESCs and critical drawback of iPSCs necessitated the emergence of novel therapeutic modality as "Adult Stem Cells". The scientific and technological advancement in stem cell therapeutics aids to understand cells identity, purity and genomic instability - stability clearly. The quality and safety of cells is assured irrespective of autologous and allogenic stem cells. This transforms fatal illness into manageable conditions and in some cases may even cure a disease. Often stem cell therapy, fill an important unmet need or provide an effective alternative where there previously were none. Many recent advances facilitate adherence to treatment, halt diseases progression, and help prevent serious complications. This enables patients to live longer, healthier lives.

\section{References}

1. Thomson JA, Itskovitz-Eldor J, Shapiro SS, Waknitz MA, Swiergiel JJ, et al (1998) Embryonic stem cell lines derived from human blastocysts. Science 282: 1145-1147. [PubMed]

2. [No Authors] (2010) Human embryonic stem cell research in the US: time for change? Nat Cell Biol 12: 627. 
Citation: Vakodikar S, Thadani J, Kshatriya P (2017) A Novel Stem Cell Paradigm: Past Controversies, Present Challenges \& Future Prospects. J Stem Cell Res Ther 7: 403. doi: 10.4172/2157-7633.1000403

Page 3 of 3

3. https://plato stanford edu/entries/stem-cells/

4. http://www.aph.gov.au/About_Parliament/Parliamentary_Departments/ Parliamentary_Library/Publications_Archive/CIB/cib0203/03cib05

5. http://www.dbtindia.nic.in/wp-content/uploads/DRAFT-NGSCR-July-2017.pdf

6. de Wert G, Mummery C (2003) Human embryonic stem cells: research, ethics and policy. Human Reproduction 18: 672-682.

7. Takahashi K, Yamanaka S (2006) Induction of pluripotent stem cells from mouse embryonic and adult fibroblast cultures by defined factors. Cell 126 : 663-676. [PubMed]

8. Gutierrez-Aranda I, Ramos-Mejia V, Bueno C, Munoz-Lopez M, Real PJ, et al. (2010) Human induced pluripotent stem cells develop teratoma more efficiently and faster than human embryonic stem cells regardless the site of injection. Stem Cells. 28: 1568-1570. [PubMed]

9. Riggan K (2010) An Update on the Frontlines of Alternatives to Embryonic Stem Cell Research 2011. The centre for Bioethics \& Human Dignity 17: 3-4

10. Sakthiswary R, Raymond AA (2012) Stem cell therapy in neurodegenerative diseases: From principles to practice. Neural Regen Res 7:1822-1831. [PubMed]

11. Huang Y, Enzmann V, Ildstad ST (2011) Stem cell-based therapeutic applications in retinal degenerative diseases. Stem Cell Reviews 7: 434-445. [PubMed]

12. Digirolamo CM, Stokes D, Colter D, Phinney DG, Class R, et al. (1999) Propagation and senescence of human marrow stromal cells in culture: a simple colony-forming assay identifies samples with the greatest potential to propagate and differentiate. Br J Haematol 107: 275-281. [PubMed]
13. Haniffa MA, Collin MP, Buckley CD, Dazzi F (2009) Mesenchymal stem cells: the fibroblasts' new clothes? Haematologica 94: 258-263. [PubMed]

14. Lin HR, Heish CW, Liu CH, Muduli S, Li HF, et al. (2017) Purification and differentiation of human adipose-derived stem cells by membrane filtration and membrane migration methods. Sci Rep 7: 40069. [PubMed]

15. Basu S, Campbell, HM, Dittel, BN, Ray A (2010) Purification of specific cell population by fluorescence activated cell sorting (FACS). J Vis Exp [PubMed]

16. Boozer S, Lehman N, Lakshmipathy U, Love B, Raber A, et al. (2009) Global Characterization and Genomic Stability of Human MultiStem, A Multipotent Adult Progenitor Cell. J Stem Cells 4: 17-28. [PubMed]

17. Kundrotas G, Gasperskaja E, Slapsyte G, Gudleviciene Z, Krasko J, et al (2016) Identity, proliferation capacity, genomic stability and novel senescence markers of mesenchymal stem cells isolated from low volume of human bone marrow. Oncotarget 7: 10788-10802. [PubMed]

18. Wang Y, Zhang Z, Chi Y, Zhang Q, Xu F, et al. (2013) Long-term cultured mesenchymal stem cells frequently develop genomic mutations but do not undergo malignant transformation. Cell Death Dis 4: e950. [PubMed]

19. Lockhart R, Aronowitz JE, Birnbaum Z, Hakakian C (2016) Quality Contro Considerations for Clinical Use of Stromal Vascular Fraction (SVF) Based Therapies in the United States. Stem Cell Research \& Therapeutics.

20. Mei Feng Aili Lu, Hongxia Gao, Caiwen Qian, Jun Zhang et al. (2015) Safety of allogenic umbilical cord blood stem cells Therapy in Patients with Severe Cerebral Palsy: A Retrospective Study. Stem Cells Int 325652: 7. [PubMed]

21. Hernigou P, Homma Y, Flouzat-Lachaniette $\mathrm{CH}$, Poignard $\mathrm{A}$, Chevallier $\mathrm{N}$, et al. (2013) Cancer risk is not increased in patients treated for orthopaedic diseases with autologous bone marrow cell concentrate. J Bone Joint Surg Am 95: 22152221. [PubMed] 